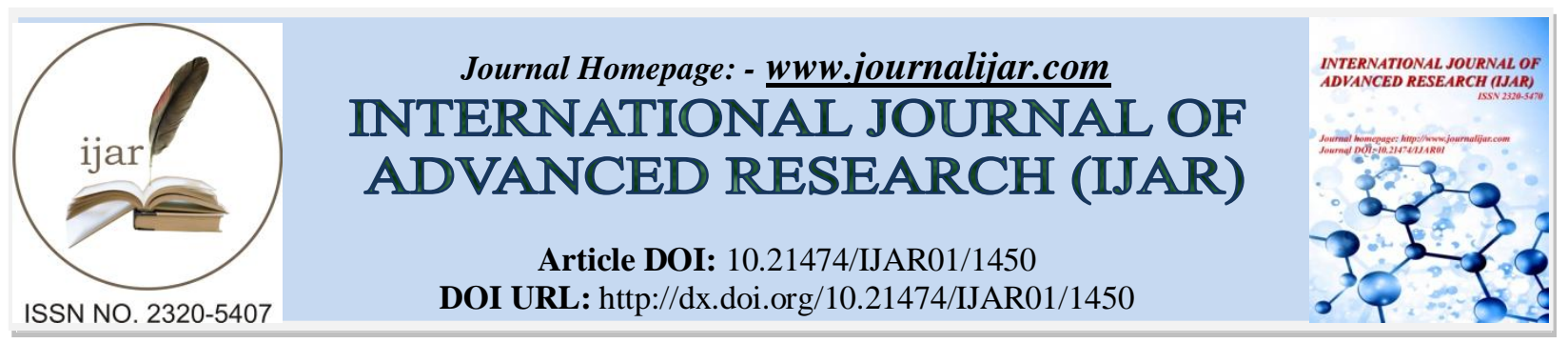

RESEARCH ARTICLE

\title{
BRUCHIDS INFESTATION ON SEEDS OF SOME FOREST TREES.
}

Ajay Singh ${ }^{1}$, Shiwani Bhatnagar ${ }^{2}$, Sangeeta Singh ${ }^{2}$ and Parveen Goran ${ }^{2}$.

1. Lachoo Memorial College of Science and Technology Shastri Nagar, Jodhpur.

2. Forest Protection Division, Arid Forest Research Institute, New Pali Raod, Jodhpur.

\section{Manuscript Info}

Manuscript History

Received: 12 July 2016

Final Accepted: 18 August 2016

Published: September 2016

Key words:-

seeds, percent infestation, Bruchidius

albizziae, Bruchidius andrewesi

\begin{abstract}
In the present study infestation by bruchids on the pods/seeds of some forest tree species was recorded. The findings revealed a 60.36 percent infestation of Bruchidius albizziae on Albizia lebbak and 11.13 percent infestation of Bruchidius andrewesi on Acacia senegal. Whereas Pongamia pinnata, Colophospermum mopane, Leucaena leucocephala and Tectona grandis were found free from bruchid infestation.
\end{abstract}

Copy Right, IJAR, 2016,. All rights reserved.

\section{Introduction:-}

Many tree species are subject to infestation by bruchid beetles of the family Bruchidae (Coleoptera). About 30 species of pulse beetles or seed beetles are found to be serious pests in the world (Kingsolver, 2004). Predation by bruchid beetles, which lay their eggs on ripening pod, has been shown to cause negative effect on seed viability (ElAtta, 1993; Mucungazi, 1995; Miller, 1996; Walter and Milton, 2003 and Schelin et al., 2004). The larva of bruchid beetles enter the seeds by drilling and feeds on the embryo and endosperm leaving most of the infested seeds nonviable, which may threaten their population (El-Atta, 1993). Many species show substantial reduction in seed germination under bruchid beetles infestation (Rohner and Ward, 1999).

In an investigation from Pakistan it was found that $86 \%$ of the seed-infesting insects belonged to the order Coleoptera and the rest under order Lepidoptera and Hymenoptera (Wali ur Rehman, 1995). Coleopteran insect have most pronounced host specificity, whereas Hymenoptera and Lepidoptera are more general feeders (Auld 1991). Females of coleopteran insect generally lay eggs on or inside fruits, or they glue their eggs directly to seeds that are exposed in dehiscent pods or are found on the soil surface (Southgate, 1979). Larval stage is the destructive life stage of this order which feed entirely within seed, making their detection and control difficult, while adults live free and feed on pollen and nectar (Gupta et al., 2009).

In some cases, seed-beetle larvae may attack a majority of seeds in the local plant population, but infestation rates of some hosts can be chronically low (Miller, 1994a; Takakura, 2002). In some cases, the insect clearly acts as a seed predator; larval feeding effectively kills the embryo or removes so much endosperm that the seed cannot germinate (Camargo Ricalde et al., 2004; El Atta, 1993; Tomaz et al., 2007).

The present study was conducted to identify and record seed infestation by bruchids on the pods/seeds of Albizia lebbak, Pongamia pinnata, Acacia senegal, Colophospermum mopane, Leucaena leucocephala and Tectona grandis in field.

Corresponding Author: - Ajay Singh.

Address:- Lachoo Memorial College of Science and Technology Shastri Nagar, Jodhpur. 


\section{Material and methods:-}

To assess percentage seed infestation due to bruchids (Coleoptera), pods/ fruits of Albizia lebbak, Pongamia pinnata, Acacia senegal, Colophospermum mopane, Leucaena leucocephala and Tectona grandis were collected and the damage done by insect pests was examined. Observations on different parameters viz., length of pod, no. of seeds per pod, no. of infested seeds per pod were recorded to calculate the percent insect infestation.

\section{Result and Discussion:-}

The data on the above parameters revealed a 60.36 percent infestation of Bruchidius albizziae on the seeds of Albizia lebbak and 11.13 percent infestation of Bruchidius andrewesi (Pic) on the seeds of Acacia senegal. Seeds of other trees under study were found to free from bruchids infestation (Table 1).

\begin{tabular}{|l|l|l|l|l|}
\hline Name of Species & $\begin{array}{l}\text { Average Length } \\
\text { of pod }(\mathbf{c m})\end{array}$ & $\begin{array}{l}\text { Average No. of } \\
\text { seeds per pod }\end{array}$ & $\begin{array}{l}\text { Average No. of } \\
\text { infested seeds }\end{array}$ & $\begin{array}{l}\text { Percent infestation } \\
\text { (No. of infested seeds x 100 } \\
\text { /total no. of seeds) }\end{array}$ \\
\hline Albizia lebbak & $22.68 \pm 0.43$ & $10.28 \pm 0.33$ & $6.22 \pm 0.48$ & $60.36 \pm 4.02$ \\
\hline Leucaena Leucocephala & $18.95 \pm 0.29$ & $22.18 \pm 0.33$ & 0.00 & 0.00 \\
\hline Pongamia pinnata & $4.1 \pm 0.05$ & $0.28 \pm 0.08$ & 0.00 & 0.00 \\
\hline $\begin{array}{l}\text { Colophospermum } \\
\text { mopane }\end{array}$ & $3.8 \pm 0.05$ & 1.00 & 0.00 & 0.00 \\
\hline Tectona grandis & $1.25 \pm 0.02$ & 1.00 & 0.00 & 0.00 \\
\hline Acacia senegal & $7.2 \pm 0.03$ & $3.8 \pm 0.12$ & $0.42 \pm 0.10$ & $11.13 \pm 2.5$ \\
\hline
\end{tabular}

Table 1:- Pod characteristics and seed infestation.

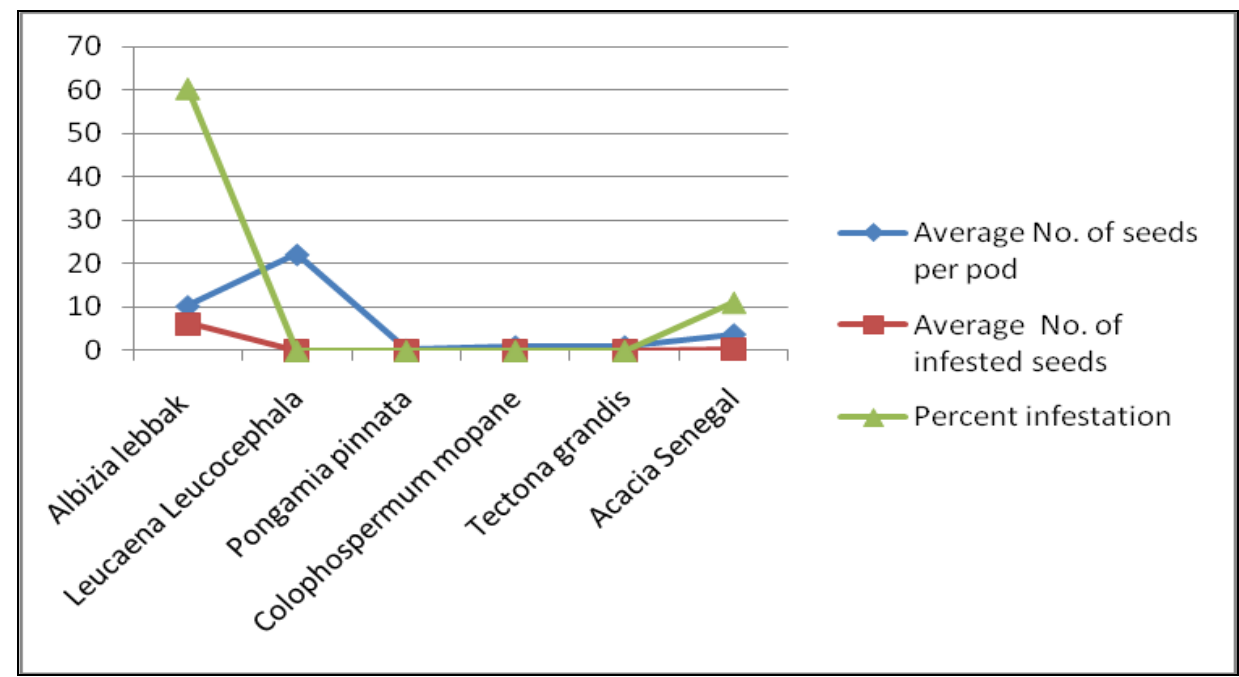

\section{Percentage seed infestation on different tree species}

Scale

$\mathrm{Y}$ axis $=$ Percent infestation, Average No. of seeds per pod, Average No. of infested seeds

$\mathrm{X}$ axis $=$ Name of species

Bruchid beetles larvae can exploit a considerable proportion of the cotyledons and thus infestations can have an enormous negative effect on seeds viability and seedling vigour. Vir (1996) reported that no seeds of the leguminous trees Prosopis cineraria, Prosopis juliflora, Acacia tortilis, Acacia senegal and Albizia lebbeck (the major component of afforestation programmes and sand dune stabilization works) damaged by bruchids, germinated. Ponnuswamy (1990) found infestation of a bruchid, Bruchus sparsimaculatus on the pods of Albizia lebbeck. In a field studies in Jodhpur, Rajasthan, Ahmed et al., (1995) reported 10\% damage (by weight) to seeds of Albizia lebbeck by Bruchidius albizziae. 
No previous report on seed infestation by Bruchidius andrewesi (Pic) on Acacia senegal was found available. However, Patel et al., (2008) reported that two species of bruchids, i.e. Bruchus bilineatopygus Pic. and Caryedon serratus Olivier infest the seeds of Acacia senegal. In a similar finding by Patel and Singh (2010), seed infestation of $21.6 \%$ due to bruchids (Coleoptera) in the seeds of Acacia senegal was recorded. Bhasin and Roonwal (1954) accounted that larva of Bruchidius andrewesi damage seeds of Acacia leucophloea. It has also been recorded as a serious pest of pods and seeds of Acacia tortilis by Vir and Jindal (1994).

\section{Acknowledgement}

The authors are thankful to Dr. V.V. Ramamurthy and Madam Sushila Joshi, Division of Entomology, IARI, Delhi for identifying the insect specimen and Director AFRI (Arid Forest Research Institute), Jodhpur for providing necessary facilities to carry out this work.

\section{References:-}

1. Ahmed SI, Kumar S, Gaur M, (1995). Seasonal fluctuations in the population of Bruchidius albizziae Arora and its effects on seeds of Albizzia lebbeck (L.) Benth. in an Indian desert. Antenna (London), 19(3):106.

2. Auld, T.D. (1991). Patterns of predispersal seed predators in the Fabaceae of the Sydney Region, south-eastern Australia. Australian Journal of Zoology, 39(5): 519-528.

3. Bhasin, J. D and Roonwal M.L (1995). List of insect pest of forest plants in India and the adjacent countries. Indian Forest Bulletin, 171 (X), Part II: 5-93.

4. Camargo-Ricalde, S.L., Dhillion, S.S., Garcia-Garcia, V., (2004). Phenology, and seed production and germination of seven endemic Mimosa species (Fabaceae: Mimosoideae) of the Tehuacan-Cuicatlan Valley, Mexico. Journal of Arid Environments, 58: 423-437.

5. El-Atta, H.A., (1993). The effect of Caryedon serratus Olivier (Col., Bruchidaee) on viability and germination of seeds of Acacia nilotica (L. Willd. Ex Del.) in the Sudan. Forest Ecology and Management, 57 (1-4): 169177.

6. Gupta, Kavita, B. Lal, Charan Singh and Ruquaeya Bano (2009). Detection and identification of insects and mites in quarantine. In: V. Celia Chalam, Kavita Gupta, Shashi Bhalla, Rajan and R.K. Khetarpal (eds) Biosecurity and Biosafety Policies, Procedures and Issues, National Bureau of Plant Genetic Resources, New Delhi, India, pp 348 -350.

7. Kingsolver, J.M. (2004). Handbook of the Bruchidae of the United States and Canada (Insecta, Coleoptera) Vol I. United States Department of Agriculture, Technical Bulletin Number, 1912: P.340

8. Miller, M.E., (1996). Dispersal of Acacia seeds by ungulates and ostriches in an African savanna. J. Trop. Ecol., 12: 345-356.

9. Miller, M.F., (1994a). Large African herbivores, bruchid beetles and their interactions with Acacia seeds. Oecologia, 97: 265-270.

10. Mucungazi, P., (1995). Effects of bruchid beetles on germination and establishment of Acacia species. African Journal of Ecology, 33 (1): 64-70.

11. Schelin, M. M. Tigabu, I. Eriksson, L. Sawadogo and P.C. Oden, (2004). Predispersal seed predation in Acacia macrostachya, its impact on seed viability and germination to scarification and dry heat treatments. New Forests, 27 (3): 251-267.

12. Southgate, B.J., (1979). Biology of Bruchidae. Annual Review of Entomology 24, 449-473.

13. Takakura, K., (2002). The specialist seed predator Bruchidius dorsalis (Coleoptera: Bruchidae) plays a crucial role in the seed germination of its host plant, Gleditsia japonica (Leguminosae). Functional Ecology, 16: 252257.

14. Tomaz, C.A., Kestring, D., Rossi, M.N., (2007). Effects of the seed predator Acanthoscelides schrankiae on viability of its host plant Mimosa bimucronata. Biological Research, 40: 281-290.

15. Vir, Satya (1996). Bruchid infestation of leguminous trees in the Thar Desert. Tropical Science, 36(1):11-13.

16. Satya Vir and S.K. Jindal (1994). Fruit infestation of Acacia tortilis (Forsk) Hyne by Bruchidius andrewesi Pic. (Coleoptera: Bruchidae) in the Thar Desert. Forest Ecology and Management.70 (1-3): 349-352.

17. Walter, M. and S.J. Milton, (2003). The production, storage and viability of seeds of Acacia karroo and A. nilotica in grassy savanna in Kwazulu-Natal, South Africa. Afr. J. of Ecol., 41: 211-217.

18. Wali ur Rehman (1995).Studies of seed insect pests of forest trees. Pakistan Jour. For. 43:1, 27-31. 